Гріненко О. І., канд. військ. наук, доцент;

Кутовий О. П., канд. техн. наук, ст. наук. співроб.;

Шапталенко M. I., канд. техн. наук (ORCID: 0000-0001-8343-694X)

Центр воєнно-стратегічних досліджень Національного університету оборони України імені Івана Черняховського, Київ

\title{
Мобілізаційні спроможності оборонного сектору національної економіки України: погляди на ефективність
}

Резюме. У статті розглянуто питання оцінювання ефективності мобілізаційних спроможностей національної економіки для задоволення потреб Збройних Сил України та інших військових формувань. Уточнено понятійний апарат, який визначає зміст мобілізаційних спроможностей національної економіки України.

Ключові слова: мобілізаційні спроможності; оборонний сектор національної економіки України.

Постановка проблеми. Під час виконання визначених завдань щодо забезпечення військ (сил) озброєнням, військовою технікою (ОВТ), іншими матеріально-технічними засобами (МТ3), фахівці Міністерства оборони України (МО України), Генерального штабу Збройних Сил України (ГШ ЗС України) складають замовлення на покриття бойових втрат i витрат, які прогнозуються. До того ж, не завжди визначається номенклатура ОВТ i MT3, яка потрібна найперше, у якій кількості тощо. Без певних даних залишається невизначеним, коли можна очікувати їх надходжень.

Пропонується розглянути можливі шляхи вирішення питання ефективного ресурсного забезпечення потреб Збройних Сил України через інструментарій економічних спроможностей галузей економіки.

Аналіз основних досліджень i публікацій. У публікаціях [1-4] висвітлюється досвід провідних країн світу щодо організації управління підприємствами 3 виробництва OBT і MT3, які орієнтовані на використання мобілізаційних спроможностей оборонних підприємств як державного сектору економіки, так і інших форм власності.

У вітчизняних публікаціях [5-7] щодо мобілізаційних спроможностей оборонного сектору національної економіки України, їх формування в умовах ринкових економічних стосунків практично відсутня інформація щодо понятійного апарату.

Метою статті $\epsilon$ оцінювання стану мобілізаційних спроможностей національної економіки, для задоволення потреб Збройних Сил України та інших військових формувань, показників їх ефективності, уточнення понятійного апарату.

Виклад основного матеріалу. Для вирішення завдань забезпечення потреб оборони держави матеріально-технічними ресурсами використаються можливості оборонно-промислового комплексу України (ОПК) [8] - сукупність органів державного управління, підприємств, установ і організацій промисловості та науки, що розробляють, виробляють, модернізують i утилізують продукцію військового призначення, надають послуги в інтересах оборони для оснащення та матеріального забезпечення сил безпеки і сил оборони, а також здійснюють постачання товарів військового призначення та подвійного використання, надання послуг військового призначення під час виконання заходів військово-технічного співробітництва України 3 іншими державами.

Завдання та потенціал ОПК України обмежені виробленням оборонної продукції та не охоплює завдання забезпечення роботи потенціалу всієї економіки держави та забезпечення життєдіяльності населення, частина якого працює зокрема i на підприємствах ОПК. А таке завдання передбачено законодавством [9]. Йдеться про підприємства транспорту, зв'язку, енергетики, будівництва, сільського господарства, системи медичного, ветеринарного, санітарноепідемічного, епізодичного забезпечення, метеорології, видобутку природних ресурсів та ï переробки тощо. Загроза втрати цих підприємств i населення від різних факторів зовнішнього та внутрішнього впливу, руйнування економіки загалом 3 причин невиконання заходів забезпечення іiі діяльності призводять до втрати сенсу ведення успішної 
оборони держави. Для ефективного вирішення завдань оборони держави наявним економічним потенціалом вважається за доцільне розглядати більш широке коло підприємств, яке пропонується називати оборонним сектором національної економіки (OCHE).

Під ОСНЕ пропонується розуміти специфічну частину економіки держави, до якої належать охоплені єдиним керівництвом сукупність центральних органів виконавчої влади, інших державних та недержавного органів управління, органів місцевого самоврядування, науково-дослідних, дослідноконструкторських закладів, підприємств галузей національної економіки різних форм власності, на яких задіяні трудові ресурси відповідної кваліфікації, та які вирішують завдання розроблення, виробництва, модернізації і утилізації продукції військового призначення, матеріального забезпечення та надання послуг в інтересах оборони, забезпечують функціонування економіки загалом і життєдіяльність населення.

Зі свого боку термін "спроможність" визначає здатність до здійснення будь-чого, за наявності сприятливих умов та обставин, які забезпечують можливість певних дій [10].

Тоді мобілізаційні спроможності ОСНЕ можна визначити як властивості специфічної частини економіки держави, які забезпечують розгортання військового (мобілізаційного) виробництва у визначених потребах, зміну економічних пропорцій в інтересах всебічного збільшення виробництва військової продукції, перебудову роботи певної кількості органів управління державою та виробництвом, переведення роботи інформаційного простору, трудових ресурсів, промисловості, транспорту, зв'язку, енергетики, будівництва, сільського господарства, системи медичного, ветеринарного, санітарно-епідемічного забезпечення, видобутку природних ресурсів, формування системи життєзабезпечення населення в інтересах задоволення потреб особливого періоду, забезпечення живучості та стійкості господарчого механізму держави, зміни діяльності наукових i дослідноконструкторських закладів для задоволення потреб оборони тощо [11].

На теренах України залишилося багато підприємств, науково-виробничих установ як безсистемних фрагментів галузей ОПК колишнього СРСР. Мобілізаційні спроможності таких фрагментів галузей ОПК, що залишились, виявились вкрай обмеженими. Наявні підприємства ОПК
України у своїй більшості виявились неспроможними відновити втрачені коопераційні стосунки та забезпечити випуск продукції за замкнутим циклом, виконувати завдання випуску кінцевої військової продукції.

Під замкнутим циклом розуміється така організація виробництва продукції, під час якої відбувається процес виготовлення зразка від його замовлення до готовності та передачі замовнику одним, або декільками підприємствами національної економіки, які діють у кооперації.

Під показником ефективності (якості) мобілізаційних спроможностей ОСНЕ пропонується вважати рівень здатності виробляти ним за замкнутим циклом певну номенклатуру оборонної продукції, надання певних послуг i робіт. Кількісно показник ефективності (якості) мобілізаційних

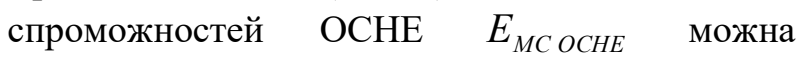
визначити як обсяг продукції, послуг і робіт, які здійснюються за замкнутим циклом Пр до кількості всієї продукції та послуг Пр що потрібні для оборони держави:

$$
E_{\text {MС ОСНЕ }}=\frac{\Pi p_{3 Ц}}{\Pi p_{\text {nomp }}} . \text { (1) }
$$

У країнах світу показник ефективності мобілізаційних спроможностей оборонного сектору національної економіки різний і навіть у провідних державах світу не має стовідсоткового значення. В Україні цей показник постійно підвищується, оскільки держава здійснює заходи щодо реформування національної економіки.

На показник ефективності мобілізаційних спроможностей оборонного сектору економіки впливає багато факторів, а саме:

значна технічна складність і неймовірна висока вартість озброєнь, особливо космічних, авіаційних, ракетних та зенітно-ракетних систем та комплексів, високоточних боєприпасів;

поява довготермінових виробничих процесів (рік і більше);

підвищення вимог до кваліфікації робітників і інженерів;

зростання рівня кооперації в діяльності численних субпідрядників i постачальників комплектуючих;

живучість виробничих потужностей тощо.

Усе це обумовлює проблемний характер ресурсного забезпечення мобілізаційних спроможностей оборонного сектору економіки, 
організації та здійснення процесу мобілізаційного планування.

Мобілізаційне планування проводиться для завчасного визначення завдань, які необхідно вирішувати ОСНЕ в особливий період, та обсягів ресурсів і часу, необхідних для їх вирішення. Основним документом, який $€$ результатом мобілізаційного планування $€$ план мобілізаційної підготовки національної економіки. Мобілізаційне планування проводиться в рамках стратегічного i оборонного планування держави і є складним системним процесом.

Щоб мати певну номенклатуру виробництва продукції, послуг та робіт, на стратегічному рівні планування потрібно провести повний цикл управлінської діяльності: 'ясування потреб; оцінювання стану та проблем; прийняття рішення на дії; постановка завдання на планування; організація управління робочим процесом i всебічне забезпечення дій; здійснення контролю та надання допомоги [12].

У процесі управлінської діяльності важливим $\epsilon$ оцінювання спроможностей країни щодо задоволення потреб ЗС України, інших військових формувань, функціонування державних і недержавних органів управління, населення, безпосередньо самої економіки, як у мирний час, так і в особливий період.

Початковий потенціал або можливості вітчизняного ОСНЕ щодо надання послуг, створення та виробництва необхідної номенклатури ОВТ i MT3, які мають встановлені бойові і технічні властивості, характеризуються: наявністю технологій, технологічного оснащення, технологічної документації, виробничих потужностей, навченого персоналу, запасів сировини i енергетичних ресурсів щодо виготовлення певної номенклатури ОВТ за замкнутим циклом.

Отже, проведення системного оцінювання мобілізаційних спроможностей оборонного сектору економіки дасть змогу якісно підготуватися для прийняття стратегічних рішень у сфері мобілізаційної підготовки економіки, а саме визначити: який інститут генеральних конструкторів мати, які конструкторські бюро за профілем діяльності утримувати, дослідні виробництва створювати;

які ОВТ, ракети, боєприпаси, складні вузли i агрегати, на виробництво яких потрібно багато часу, елементну базу для електроніки та автоматики тощо держава вироблятиме за замкнутим циклом, які в кооперації і з ким, які закуповуватимуться, у кого і в якій кількості;

на яких підприємствах та які мати мобілізаційні потужності, ступінь їх захищеності від сучасних засобів ураження;

які критичні технології, зразки ОВТ необхідно придбати за офсетними схемами, яка номенклатура озброєнь братиметься в лізинг; які потужності необхідні в державі для виробництва електроенергіï, пального, видобутку нафти, газу, технічної та питної води, обсяги їх зберігання та споживання, обсяги їх закупівлі за кордоном в мирний час та особливий період;

які запаси ОВТ і М3 мати в стратегічних запасах, де і як їх зберігати;

які запаси сировини, вузлів, агрегатів та комплектуючих утримувати в мобілізаційних резервах.

Зазначене має знаходити відображення у воєнно-політичних директивах i державному оборонному плануванні.

Визначившись у державі 3 номенклатурою, технологіями, виробниками, наступає час прийняття рішень яке $\mathrm{i}$ в якій кількості ОВТ і МТ3 утримувати у військах (силах), стратегічних запасах, виробляти (замовляти за кордоном тощо), надавати послуги в особливий період. Це завдання вирішує мобілізаційне планування в системі державного оборонного планування. Воно проводиться за допомогою розроблення на основі Стратегічного замислу на застосування Збройних Сил України та інших складових сил оборони сукупності плануючих документів, які визначають потреби оборони та порядок їх задоволення. Наслідками цієї управлінської роботи стануть підготовлені та доведені до органів управління i виконавців завдання, зокрема $\mathrm{i}$ щодо створення мобілізаційних потужностей як частини виробничих потужностей підприємств, установ і організацій, які створюються в мирний час для виробництва продукції, виконання робіт та надання послуг щодо задоволення потреб оборони держави в особливий період.

Отже, створення (формування) мобілізаційних спроможностей - це процес набуття структурною одиницею (елементом) OCHE або ї сукупністю (галуззю) властивостей виконувати певні завдання (мобілізаційні замовлення) за певних умов обстановки, ресурсного забезпечення та відповідно до встановлених стандартів. Вони залежать від ефективності використання взаємозалежних і взаємозумовлених ресурсів: виробничих, трудових, природних, фінансових, 
наукових, науково-технічних, управлінських, інформаційних тощо [13]. Тобто, через управління зазначеними ресурсами досягаються відповідні показники мобілізаційних спроможностей ОСНЕ (рис. 1).

Під час набуття спроможностей ОСНЕ виробляти за замкнутим циклом певну номенклатуру оборонних ресурсів необхідно встановити кількісні та часові показники задоволення потреб ЗС України в ОВТ і МТЗ в особливий період. Під кількісним показником розуміється обсяг озброєння, військова техніка і ракети, боєприпаси, інші матеріальні засоби у встановлених розрахунковопостачальних одиницях тощо.

Під часовими показниками розуміються: години, доби, місяці, квартали, півріча, роки. Це вкрай важливо в умовах особливого періоду для своєчасного доукомплектування з'єднань і військових частин, що приводяться в готовність до виконання завдань за призначенням, відмобілізуються (формуються), для поповнення втрат і витрат ресурсів під час застосування військ (сил).
Спроможності у сфері нарощування кількісно-часових показників характеризуються темпом мобілізаційного розгортання виробничих потужностей (ОПК, галузі, підприємства). Під зазначеним розуміється швидкість збільшення випуску продукції та послуг в одиницю часу використовуючі основні та резервні потужності підприємств, що не використовувались у мирний час i розконсервації мобілізаційного потенціалу. Саме швидкість мобілізаційного розгортання виробничих потужностей підприємств дає змогу досягти піковий рівень виробництва максимальний кількісний показник виробленої продукції, або наданих послуг в одиницю часу (годину, зміну, добу, місяць, квартал тощо). Потрібно мати на увазі, що суттєво на темп мобілізаційного розгортання виробничих потужностей (ОПК, галузі, підприємства), досягнення пікового рівня виробництва впливає наявність вузьких місць в організації виробництва - місця у виробничому ланцюзі 3 обмеженим виробничим потенціалом, без збільшення якого неможливо досягти збільшення виробництва продукції загалом.

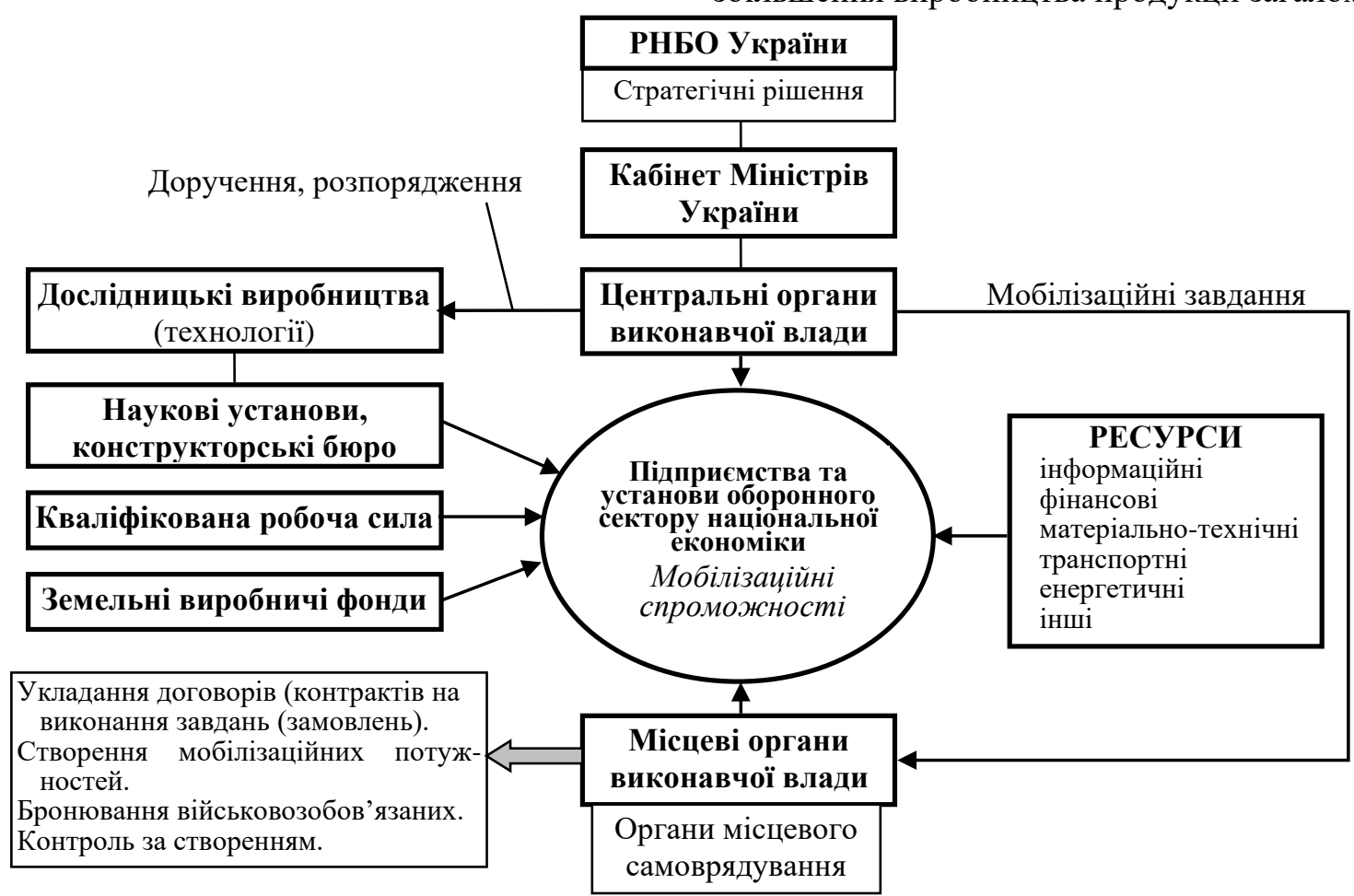

Рис. 1. Схема формування мобілізаційних спроможностей підприсмствами оборонного сектору національної економіки

Максимальне значення показника виробленої продукції, або виконаних робіт, наданих послуг безпосередньо пов'язане 3 режимом роботи обладнання (змінністю) підприємства, який характеризує час повнозмінного використання встановленого обладнання [14].
Поряд 3 режимом роботи обладнання на показник виробленої продукції впливає продуктивність праці. Підвищення продуктивності праці - головний фактор зростання ефективності та прогресивності підприємства. Вона безпосередньо пов'язана із зниженням трудомісткості продукції, оптимальністю використання робочої сили, 
підвищенням кваліфікації робітників, раціональністю організації та стимулювання праці [15].

Приймаючи управлінські рішення під час планування мобілізаційних завдань (замовлень) вкрай важливо враховувати тривалість технологічного циклу виробництва. Основою виробничого циклу є технологічний цикл, який складається $з$ низки операцій, тому значну увагу приділяють вибору виду руху предметів праці з операції на операцію [16].

Технологічний час виробництва може бути критично неприйнятним. Так, наприклад, технологічний час виготовлення літака F-15 складає тридцять шість місяців, виготовлення танка "Абрамс" - двадцять два місяці. Ці терміни залежать, насамперед, від високої складності сучасної зброї. Навіть порівняно простий за конструкцією 155-міліметровий високоточний снаряд "Коперхенд" складається 31200 деталей. Тому в провідних країнах світу приймаються рішення щодо накопичення в мирний час у мобілізаційних запасах певної кількості ОВТ та MT3 відповідної номенклатури, особливо технологічно складної.

Отже, спроможності економіки задовольняти потреби в ОВТ і MT3 за потрібними обсягами та часом виступають показниками ефективності роботи ОСНЕ України. Генеральний штаб Збройних Сил України визначає потреби в ресурсах, Міністерство оборони України разом 3 органами управління інших військових формувань, іншими центральними органами виконавчої влади під керівництвом Міністерства економічного розвитку і торгівлі України (Мінекономро́звитку України) готують проєкт мобілізаційного плану національної економіки України на особливий період. Кабінет Міністрів України визначає i затверджує основні показники мобілізаційного плану національної економіки та мобілізаційні завдання (замовлення) центральним і місцевим органам виконавчої влади, іншим державним органам тощо. У разі оголошення мобілізації Уряд організовує переведення національної економіки на функціонування в умовах особливого періоду. Крім наведених суб'єктами управління формуванням необхідних мобілізаційних спроможностей ОСНЕ України є:

Верховна Рада України;

Апарат Президента України;

Рада національної безпеки i оборони України; центральні органи виконавчої влади, які здійснюють керівництво у сфері оборони України, розвитку продуктивних сил, впровадження новітніх технологій та інновацій, військово-технічного співробітництва;

інші державні та недержавні органи управління;

місцеві державні адміністрації та органи місцевого самоврядування;

урядові комісії, міжгалузеві та відомчі робочі групи.

Об'єктами управління формуванням мобілізаційних спроможностей оборонного сектору національної економіки $\epsilon$ : органи виконавчої влади; інші державні та недержавні органи управління; наукові установи, конструкторські бюро; підприємства, установи та організації.

Управлінський процес суб'єктами управління після проведення попередньої класичної роботи передбачає організацію створення виробничих потужностей, підготовки і передачі технологій, технологічного оснащення, підготовки та перерозподілу необхідного персоналу, передачу та контроль ефективності використання інформаційних, наукових, науково-технічних, фінансових, природних та інших ресурсів тощо. Ефективність управлінської діяльності вимірюється повнотою, своєчасністю, вартістю проведення заходів у сфері оборони та отриманим результатом.

Висновок. Поступовий перехід економіки України на сучасні ринкові відносини сформував такі умови виробництва, 3 якими колишня система мобілізаційної підготовки національної економіки виявилася несумісною. Тенденція зниження рівня мобілізаційної готовності придбала обвальний характер, чим обумовлена необхідність формування нових підходів до створення національної і регіональної систем мобілізаційної підготовки 3 урахуванням ринкових механізмів. Це потребує коригування та появу нового законодавства держави та насамперед нового закону України про мобілізаційну підготовку і мобілізацію.

Для успішного вирішення завдань оборони держави наявним економічним потенціалом вважається за доцільне розглядати більш широке коло підприємств - оборонний сектор національної економіки.

Під показником ефективності (якості) мобілізаційних спроможностей ОСНЕ пропонується вважати рівень здатності виробляти ним за замкнутим циклом певну 
номенклатуру оборонної продукції, надання певних послуг і робіт.

Подальші дослідження доцільно присвятити питанням підвищення ефективності функціонування системи мобілізаційного планування у сфері підготовки національної економіки до задоволення потреб сил оборони.

\section{СПИСОК ВИКОРИСТАНОЇ ЛІТЕРАТУРИ}

\section{1. В. Яровой. Розвиток оборонно-промислового} комплексу Республіки Польщі під час і1ї інтегрування в НАТО та Європейський союз.

2. В. Варнавский "Партнерство государств и частного сектора". - М : НАУКА. 2005

3. О. Кутовий. "Шляхи оснащення Збройних Сил України озброєнням, військовою технікою та матеріально-технічними засобами в особливий період”. Збірник наукових праць ЦВСД НУОУ імені Івана Черняховського. № 1 (53). - НУОУ. 2015. - С. 81-87.

4. "Методологічні аспекти оцінки мобілізаційних спроможностей національної економіки, науковометодичне видання".// посібник, інв. 16843 - Київ : Міністерство оборони України. - 2017 - С. 198-210.

5. А. Петренко. Рекомендації 3 оборонного планування на основі спроможностей в Міністерстві оборони України та Збройних Силах України”. МО України. // 13.06.2017 р. № 5789/3/3. - 12 с.

6. А. Петренко. Рекомендації 3 порядку організації проведення оцінювання спроможностей у Збройних Силах України, затверджені Міністром оборони України 07.12.2017 p.
7. Крикун П. М., Павленко В. І., Кравчук В. В. Розвиток оборонного планування як складової національної системи планування у сфері безпеки та оборони за умов наближення до процедур i стандартів НАТО. // Збірник наукових праць ЦВСД НУОУ. - К., 2017. - № 2 (60). - С. 44-48.

8. Закон України "Про національну безпеку України" 21.06.2018 № 2469-VIII.

9. Закон України "Про мобілізаційну підготовку та мобілізацію” 21.10.1993 № 3543-XII.

10. Словник української мови: в 11 томах. Академічний тлумачний словник - Том 9, 1978. - 605 c.

11. Н. Огарков и др. "Военный энциклопедический словарь”. Воениздат. Москва, 1983. - 452 с.

12. О. Гріненко, О. Кутовий, О. Устименко. "Роль стратегічних рішень керівництва держави у формуванні завдань мобілізаційної підготовки національної економіки". Журнал Наука і оборона, 2016, № 3. - С. 10-16.

13. С. Мочерний (відп. ред.) та ін. Економічна енциклопедія: У трьох томах. Т. 1. Видавничий центр “Академія", 2000. - С. 126.

14. Економіка підприємства. Електронний ресурс //studme.com.ua/11570718/ekonomika/ pokazateli_ispolzovaniya_osnovnyh_fondov.htm.

15. Аналіз ефективності використання трудових ресурсів. Електронний ресурс https://makromablog.files.wordpress.com/.../d0b0d0bdd0 b0.

16. В. Анурьев. Справочник конструкторамашиностроителя: В 3 т. / Под ред. И. Жестковой.8-е изд., перераб. и доп. Машиностроение, 2001.ISBN 5-217-02962-5.

\section{Стаття надійшла до редакційної колегії 11.05.2019}

Гриненко А. И., канд. воен. наук, доцент;

Кутовой О. П., канд. техн. наук, ст. науч. сотрудник;

Шапталенко Н. И., канд. техн. наук, доцент

Центр военно-стратегических исследований Национального университета обороны Украины имени Ивана Черняховского, Киев

\section{Мобилизационные возможности оборонного сектора национальной экономики Украины: взгляды на эффективность}

Резюме. В статье рассмотрены вопросы оценки эффективности мобилизационных возможностей национальной экономики для удовлетворения потребностей Вооружённых Сил Украины и других воинских формирований. Уточнен понятийный аппарат, который определяет содержание мобилизационных возможностей национальной экономики Украины.

Ключевые слова: мобилизационные возможности; оборонный сектор национальной экономики Украины.

A. Grinenko, PhD (Military), assistant professor;

O. Kutoviy, PhD (Technical), senior researcher;

N. Shaptalenko, PhD (Technical), assistant professor

Center for Military and Strategic Studies of the National Defence University of Ukraine named after Ivan Cherniakhovskyi, Kyiv

Efficiency of mobilizational possibilities of defensive-industrial complex of national economy: indexes and management parameters.

Resume. The article deals with the issues of assessing the effectiveness of the mobilization capabilities of the national economy to meet the needs of the Armed Forces of Ukraine and other military formations. The conceptual apparatus has been clarified, which determines the content of the mobilization capabilities of the national economy of Ukraine.

Keywords: mobilization capabilities; the defense sector of the national economy of Ukraine. 